\begin{tabular}{c}
\hline KEMAS 13 (3) (2018) 304-313 \\
Jurnal Kesehatan Masyarakat
\end{tabular}

\title{
THE IMPACT OF ENVIRONMENTAL CHANGES CAUSED BY EARTHQUAKE TOWARD EMOTIONAL PROBLEMS OF PRESCHOOL CHILDREN
}

\author{
Vivi Triana ${ }^{1 \bowtie}$ \\ ${ }^{1}$ Faculty of Public Health, Universitas Andalas
}

\begin{tabular}{l} 
Article Info \\
\hline Article History: \\
Submitted September 2015 \\
Accepted July 2016 \\
Published March 2018 \\
\hline Keywords: \\
environmental; emotional \\
child; preschool; earthquake \\
\hline DOI \\
https://doi.org/10.15294/ \\
kemas.v13i3.3977
\end{tabular}

\begin{abstract}
Natural disasters can result in death and disability that lead to loss, grief and emotional disturbance reactions. The disorder is more common in children underwent development period. Neurological changes in children who experience Post Traumatic Syndrome Disorder (PTSD) 1.5 times greater than in adults. This study aims to determine the impact of environmental changes caused by the earthquake in Padang Pariaman district towards emotional problems of children aged 3-5 years. We used retrospective cohort study design in a population of children aged 3-5 years in September 2009. The sample was 219 people who were taken using stratified random sampling method. Data was collected by interviewing the parents through a questionnaire and analyzed using univariate and bivariate analysis. We observed a significant relationship between environment damage $(p=0.017)$, occupation $(p=0.02)$ and economic status $(p=0.03)$ with emotional problems in children. Education did not have a significant relationship with emotional problems in children.
\end{abstract}

\section{Introduction}

Psychiatric and behavioral disorders caused by various factors, including the disaster, both natural and man-made disasters resulting in a psychological trauma for all who experience it. Indonesia as one of the countries that are in the disaster-prone country, with a unique geographical position, Indonesian archipelago is located at meet point of three giant tectonic plates. This geographical position causing Indonesia prone to volcanic eruptions, earthquakes, tidal waves to tsunamis and extreme weather that could potentially cause flooding and landslides and drought. Almost all the world's natural disasters have occurred in
Indonesia and cause mass casualties (Ristrini, 2012).

The effect of disasters that occur suddenly not only cause many deaths, but also massive social disruption and outbreak of epidemic diseases, as well as the scarcity of foods so that the survivors entirely dependent on the external assistances. Systematic observations conducted on the effect of natural disasters on the human health produces a variety of conclusions, either about the effect of the disaster on health and about the most effective ways to provide humanitarian assistance (Machmud, 2009).

One disaster lately often happens in Indonesia is an earthquake, the effect may

Correspondence Address:

Email : vivietri_76@gmail.com 
cause ecological and psychosocial damages. Earthquake damage not only lead to physical problems, but also emotional, economic, social and interpersonal relationships problems. Traumatic events and stress is often found today on every individual and no exception in children after natural disasters occurred such as earthquakes, landslides and many others. They are directly or indirectly suffered from the natural disasters, all of these may cause a reaction and also stress disorder. Disasters may cause death, leading to loss reaction or sadness, physical pain, disability and emotional disturbance (Nurhasanah, 2008).

The importance of role of emotion in individual's development will be seen through the consequences that arise as a result of the children lack opportunity to get a pleasant emotional experience. Disturbance of emotions may affect on children, especially in the first years of development like delays in child development. Various developmental potential can already be known through the emotional development since the first three years of age. Natural disasters not only cause physical injury such as death, disability, and the resulting loss of material in various fields. The natural disaster also left psychological impact for the people who survived. Lost family members due to death and destroyed of the property in a short time causes the individual to be in shock state even get in depression state. Individuals who survived have to able to survive in deprivation condition (Amawidyati, 2007).

The earthquake left a psychological shock that is not easily erased, potential to cause psychological symptoms such as stress, known as Post Traumatic Syndrome Disorder (PTSD). PTSD is a complex disorder because of the symptoms that look remarkably similar to symptoms of depression, anxiety and symptoms of other psychological disorders, but not all that psychological disorders can included in the criteria for PTSD, so as to understand the complexity of the symptoms of PTSD, it is necessary to identify the difference between stress, traumatic stress, PTS and PTSD (Solichah, 2013). PTSD can occur after someone saw, heard, or experienced a great trauma or life-threatening events (Prabandari, 2015).
Children victims suffered stress and mental burden such as those experienced by adults. Psychologically, children are vulnerable to traumatized by disaster. Children are also vulnerable to disease that they experienced after the disaster. Physical and psychological condition experienced by children affected by the disaster will be strongly influenced by environmental and parents changes. Children are more likely to have post-disaster trauma than adults because children's activities were confined to learn and play, in such disaster situation these activities may not be able to do, so that children experience boredom and trauma as a result of not fulfilled of these needs, therefore the role of the parents desperately needed by children. In addition, in the situation that gives rise to stress, such as severe illness or injury, trauma and loss experience, children who are under stress conditions more likely to show the need for security and protection through their behavior (Wuri, 2008).

Muray examined the neurobiological changes that children's vulnerability to PTSD was 1.5 times greater than adults due to children are in the growth stage, particularly completion of the central nervous system (CNS). In a natural disaster, the children may lose all their possessions, including the surroundings (shelter, playground, school, friends and other places). According to Mc Dermott, the emotional distress symptoms were significantly associated with environmental damage (Murray, 2006; McDermott, 1999).

Karanci (1995), said that traumatic events and stress is often found today on every individual and no exception in children after natural disasters such as earthquakes, landslides etc. They are directly and indirectly involved in traumatic events. In the event of a natural disaster they also lost all their possessions that they have, and their surroundings (schools, playgrounds and other places). All of these can cause a reaction and post traumatic stress disorder in children. The meaning perceived by he/she who experienced a traumatic events will determine the impact it may have on him/her. Thus not all children will react the same way to a similar traumatic events, it depends on several things: the temperament of the child, the child's age, their environment/family. Children aged 
under five years old still depend on the people who care for them in getting the protection and security.

They often become powerless and passive when confronted with situations that endanger their mental health. Behavior that must be observed are: 1) Fear of the presence of strangers. 2) Anxiety separation, they seem not want to be separated from their parents or nanny/babysitter. 3).Various types of sleep problems, such as kept awake all night, nightmares and delirium, because they are not able to understand the terrifying event of natural disasters in nature. 4). Prominent anxiety if faced situations or places associated with catastrophic events experienced. 5). Decline in various stages of development already controlled a child, for example, be silent or did not even talk at all, can't resist wetting or defecate, and back thumb sucking.

Mental reaction to a child's emotional or behavioral problems indicated the child shortly after a period of difficult time / frightening experience and painful due to a traumatic event is reasonable. Immediately after experiencing a traumatic event that children often feel scared, uncomfortable, unsafe and sad and angry.

The earthquake in West Sumatra and surrounding areas is a traumatic event for victims who experience it, especially children. Disastrous experience have directly put children in a situation of helplessness and deep fear. In such situations the children are also vulnerable to PTSD and anxiety disorders. Tectonic earthquake occurred in Padang Pariaman Region resulting in physical injury and psychological problems, Ulakan and Sungai Limau sub-district are an area got quite severe damage caused by the earthquake. This study aims to prove the impact of environmental changes caused by the earthquake towards the emotional problems of children aged 3-5 years (preschool).

\section{Method}

This research used analytic observational retrospective cohort design with a quantitative approach that was supported by qualitative data. The cohort retrospective design is an observational studies that examine the relationship between exposure and disease, by selecting two or more study groups based on differences in the status of exposure, then followed over a period of time to see how many subjects in each group experienced a disease or sequel more specific; exposure and disease was already occurring before the start of the study, so the variables measured through historical records or respondent recall things that happened in his/her past. In this study, we did not intentionally give intervention, but only observe (measure), record, classify, calculate and analyze (comparing) changes in the variables in natural conditions (Arikunto, 2010).

The population were all children who at the time of the earthquake September 2009 aged 3-5 years (the time of the study have been aged 5-7 years). Subjects in this study were all children residing in the district and subdistrict Sei Limau, Ulakan, Padang Pariaman. The inclusion criteria consisted of a sample of children aged 5-7 years, children who currently were in the earthquake site and the mother willing to become respondents. Exclusion criteria in this study were children who have a chronic illness, children with disabilities / mental disorders.

The sample size was calculated based on the total population of children under five in the district of Padang Pariaman with 95\% confidence level. The sample size was 200 people. Sample size calculation was obtained from formula in the Case Control Studies for Hypothesis tests for and odds ratios by SK Lwanga and Lameshow (WHO). The sampling method in this research were using stratified random sampling method, whereas the members of the population were classified first, then all members have the same opportunity as the respondent or so-called simple random sampling technique (Arikunto, 2010). We obtained a total sample of 219 people (based on inclusion and exclusion criteria). Assessment of health needs were using a measuring instrument that has been developed by Prof. Patricia J. Allen of Yale University School of Nursing in research on "Children with Special Health Needs: National Survey of Prevalence and Health Care Needs". The measuring instrument was modified by adding some variables related to family background and parents as well as other demographic information primarily 
relates to issues of the impact of the earthquake.

Data was collected through interviews using a structured questionnaire to parents of the children (or guardian) and midwife. The questionnaire was a list that contain a series of questions about research issues. Trained interviewers visited the home or residence of the women and interviewed directly. Interviews with parents of the children or guardian; intended to seek information about: Does the child has a tendency to emotional problems after the earthquake. After data collection followed by data processing and analysis. Data already collected will be entered into a computer for data entry. Data that had been entered and cleaned, then analyzed using the program Stata 11. The independent variable was the earthquake: changes in the environment (residence), meanwhile the dependent variable was the tendency to emotional problems of children aged 3-5 years and confounding variables were included: maternal education , maternal employment status, economic status (Arikunto, 2010).

The data analysis consisted of univariate and bivariate analysis; univariate analysis was performed on a simple analysis of the variables in order to determine a general overview of the study variables (emotional problems of children, environmental damage, maternal education, maternal employment and economic status). Bivariate analysis was the analysis of the two variables were suspected related or correlated, this analysis was used to determine the relationship between the independent variable (environmental degradation, maternal education, maternal employment and economic status) with the dependent variable (child's emotional problems). We used chi-square test to determine the significance of relationship between independent and dependent variables, the relationship between the two variables is said to be significant if the $p$ value $<0.05$ with 95\% confidence level. Chi square test was also used to see the magnitude of the risk of exposure to an outcome by calculating the OR (Odds Ratio).

\section{Results and Discussion}

Padang Pariaman Regency is located $100^{\circ} 16^{\prime} 00^{\prime \prime} \mathrm{E} 0{ }^{0} 39^{\prime} 00$ " $\mathrm{S}$. The total area of Padang Pariaman district about 1.328,79 square kilometers inhabited by 390.204 people, who inhabit 10 districts. The average population density of Padang Pariaman district is 294 people per square kilo meter. The highest population density is the District Nan Sabaris that as many as 915 people per kilo square meters while the lowest is the District $2 \times 11$ Kayu Tanam that as many as 112 people per square kilo meter (BPS, 2010).

Subdistrict of Ulakan Tapakis and Sungai Limau is 2 out of 10 subdistrict in Padang Pariaman regency. Ulakan Tapakis has total area $38.85 \mathrm{~km}^{2}$ with a population of 20.189 people. The border of District of Ulakan Tapakis is North: Nan Sabaris subdistric, South: Batang Anai subdistric, West: Indonesian Ocean, East: District of Sintuk Toboh Gadang. It consists of 2 Nagari is Tapakis and Ulakan. While Sei Limau subdistrict has an area of $40.31 \mathrm{~km} 2$ with a population of 11.417 people. Sei Limau boundaries: North: Batang Gasan subdistrict, south V Koto Kampung Dalam subdistrict, west: Indonesia ocean, east: River Geringging. It consists of 2 Nagari: Nagari Pilubang and Kuranji Hilir. Subdistrict Ulakan Tapakis and Limau River is an area severely damaged due to the earthquake that occurred in 2009, not least the material loss and moral that hit the area (BPS, 2010).

Univariate analysis was used to calculate the characteristic of frequency distribution and proportion of subjects. Characteristics of subjects in relationship with the tendency of emotional problems can be identified by univariate analysis. Characteristics of research subjects in this study in detail can be seen in Table 1.

In general, the number of changes in the environment (residence) that changed, that is classified as heavily damaged was nearly half (46.1\%), while included in minor damage, more than half $(54 \%)$. For the education level of mothers who belong to the low level of education (elementary-junior high) almost half (44\%), this did not include out of school (5\%). Higher education (high school and above) was pretty much (50.6\%). It could interperted for mothers educaiton level, this area was only half the mothers were educated. For maternal employment status, which did not work when compared with had work, univariate result 
Table 1. Characteristics of Variables

\begin{tabular}{lll}
\hline Variable & $\mathrm{n}$ & $\%$ \\
\hline Children Emotional Problems & & \\
$\quad$ Suspected & 23 & 10.5 \\
$\quad$ Normal & 196 & 89.5 \\
Enviromental Damage (House) & & \\
$\quad$ Mild / Moderate & 118 & 53.9 \\
$\quad$ Severe & 101 & 46.1 \\
Mother Jobs & & \\
Houswife & 157 & 71.7 \\
Farmer & 31 & 14.2 \\
Private sector & 18 & 8.2 \\
Civil servants & 13 & 5.9 \\
Mother Education & & \\
No Education & 11 & 5.0 \\
Elementary School & 40 & 18.3 \\
Junior High School & 57 & 26.0 \\
Senior High School & 98 & 44.7 \\
$\quad$ University & 13 & 5.9 \\
Total & 219 & 100 \\
\hline
\end{tabular}

Source : Primary Data

illustrated that largely as a housewife (72.7\%).

Children who experience less emotional problems was more than children who experience no emotional problems after the earthquake. Something similar was stated by Hotmaida stating that the respondents who experienced PTSD less than the tendency of respondents who experienced PTSD (Hotmaida, 2008). Psychological disorders suffered by victims is a sadness feeling from the loss of relatives and possessions, an uncomfortable feeling at the evacuation place. It is more felt by children and elderly (Rusmiyati, 2012).

The bivariate analysis was used to determine the relationship between the independent variables (environmental changes) and the dependent variable (the tendency of emotional problems); the dependent variable and external variables (maternal education, maternal employment status, economic status). In addition, bivariate analysis was also to predict the magnitude of the incidence of risk factors of children's emotions. To look at the relationship external variables and independent variables with the dependent variable, we used chisquare test and relative risk (RR). Hypothesis testing based on $5 \%$ significance level $(p<0.05)$ and $95 \%$ Confidence Interval (CI).

In general, severe environmental (residence) damages resulting children emotional problems was 16 children (15.8\%), while milder environmental damages resulting lower children emotional problems, that was 7 children (5.9\%). Indonesia is one country that lies between the tectonic plates that have the potential of enormous natural disaster, particularly earthquakes. Earthquakes are one of the natural disasters cause much damages like death or infrastructure/environment damages. According to the Center for Research on the Epidemiology of Disasters, from a total of 27 times the earthquake (excluding tsunami), the number of victims who died as a result of the earthquake is 8232 people and 6.839.137 seriously injured victims. Victims either died or were seriously injured was the highest compared to victims by other natural disaster, when compared to the flood that nearly 48 times occurred in Indonesia during the last 10 years (the victim died 906 people, $2,102,523$ seriously wounded victims). The damage caused by the earthquake is also the greatest damage since 2005 until now, reaching 
Table 2. Chi-square Results on Enviromental Changes of House with Mother Occupation; House and Economy Status with Children Emotion Problems

\begin{tabular}{|c|c|c|c|c|c|c|c|c|}
\hline \multirow[t]{3}{*}{ Variable } & \multicolumn{4}{|c|}{ Children Emotion Problems } & \multirow[t]{3}{*}{$x^{2}$} & \multirow[t]{3}{*}{$\mathrm{p}$-value } & \multirow[t]{3}{*}{$\mathrm{RP}$} & \multirow[t]{3}{*}{$95 \%$ CI } \\
\hline & \multicolumn{2}{|c|}{ Suspected } & \multicolumn{2}{|c|}{ Normal } & & & & \\
\hline & $\mathrm{n}$ & $\%$ & $\mathrm{n}$ & $\%$ & & & & \\
\hline \multicolumn{9}{|c|}{ Enviromental Damages } \\
\hline Severe & 16 & 15.8 & 85 & 84.2 & 5.38 & $0.017^{\star}$ & 3.35 & $1.35-8.51$ \\
\hline Mild & 7 & 5.9 & 11 & 94.1 & & & & \\
\hline \multicolumn{9}{|l|}{ Education } \\
\hline Low & 13 & 12 & 95 & 88 & 0.53 & 0.47 & 1.38 & $0.58-3.3$ \\
\hline High & 10 & 9 & 101 & 91 & & & & \\
\hline \multicolumn{9}{|l|}{ Jobs } \\
\hline Work & 40 & 20.4 & 69 & 79.6 & 4.9 & $0.02^{*}$ & 0.5 & $0.31-0.98$ \\
\hline Do not work & 58 & 39.4 & 72 & 60.6 & & & & \\
\hline \multicolumn{9}{|c|}{ Economy Status } \\
\hline Low & 52 & 39.7 & 66 & 60.3 & 4.7 & $0.03^{*}$ & 1.4 & $1.06-1.91$ \\
\hline High & 36 & 21.2 & 66 & 78.8 & & & & \\
\hline
\end{tabular}

Source : Primary Data

thousands of US \$ 6.31685 million (Zein, 2014)

From statistical calculation, we obtained

RP 3.35 with a $p$-value $<0.05$, so enviromental changes caused by earthquake had significant relationship with tendency to emotional problems of children aged 1-5 years $(p<0.05)$. Natural disasters resulting in loss of all their possessions, loss of family, as well as the threat of losing their surroundings (shelter, playground, school, friends and other places). This result is supported by the opinion of Tentama (2014), which stated that teens who become survivor have to face the death of a family, fear, threats and loss of property such as clothing, home and living facilities. This condition can cause anxiety, confusion and sadness, even more severe like mental disorders. Symptoms of emotional distress was significantly related to environmental damage. The characteristic feature of the research subjects clearly could be seen in Table 2.

Analysis of relationship of the mother's education with tendency of emotional problems of children conducted to determine the relationship of the dependent variable (the tendency of emotional problems for children) with external variables (mother's education). High mother's education with a tendency to emotional problems suspect was 13 children (12\%) and low maternal education with a tendency to emotional problems suspect was 10 children (9\%). From the statistical calculation resulted $p$-value was higher than 0.05 , this data showed that the mother's education level did not have a significant relationship with a tendency to emotional problems of children.

Analysis of mother employment status with the tendency of emotional problems of children conducted to determine the relationship of the dependent variable (the tendency of emotional problems for children) with external variables (employment status of the mother). Non working mothers with the tendency of suspected emotional problems was 40 children $(20.4 \%)$ and working mothers with the tendency emotional problems suspected was 58 children (39.4\%). From statistical calculation, we obtained RP 0.5 with $p$-value $<0.05$, it showed mother employment status had significant relationship with a tendency to emotional problems of children. According to Adeola (2009), stated that there was significant relationship between employment with psychological disorders.

Statistical analysis showed that employed mother had significant relationship, however it 
was unknown why working mother had higher tendency to children emotional problems. Though, a mother who worked had very little time for their children, so that mothers are less likely to monitor the development of their children.It is probably because when earthquake occurred, many parents are traumatized too, so as to give security feeling to their children I lack. Parents may play an important role in helping children to understand and cope with disasters. A study of mental disorders and psychosocial symptoms conducted in Hurricane Katrina survivors. The survivors were experienced sleep disturbance, anxiety, depression and a tremendous worries, which was statistically significant. The factors may as strong predictor of mental disorders and psychosocial symptoms in victims was unemployed, loss of house and financial problems (Adeola, 2009).

Analysis of the relationship of mother's economic status with emotional problems of children conducted to determine the relationship of the dependent variable (the tendency of emotional problems of children) with external variables (economic status of the mother). Low economic status mothers with emotional problems tendency was 52 children (39.7\%) and high economic status mothers with emotional problems tendency was 36 children $(21.2 \%)$. From statistical calculation, we obtained RP 1.4 with a $p$-value $<0.05$, statistical analysis showed economic status of the mother did not have significant relationship with the child's tendency to emotional problems. However, practically there were visible differences, that emotional problems children suspect was higher in mothers with low economic status.

The results of this research was in line with the opinion of Heller (1986) found higher incomes and whose with higher education were prepared due to more access to sources of health information.

Changes in the environment (residence) that change (Table 2) may experience emotional problems tendency greater than changes in the environment (residence) that does not change who experience emotional problems suspected tendency. From the statistical calculation results can be interpreted changes in the environment (residence) by earthquake had significant relationship with tendency to emotional problems of children aged 1-5 years ( $p$-value $<0.05)$. This was due to the child experienced environmental change.

Children who survived the earthquake may experience painful emotional state, where they have lost one or both parents and some siblings or other family members, damaged house, as well as destroyed-schools. The shock due to these events, the sudden displacement of homes to refugee camps were believed as highrisk conditions that can be painful emotionally. The reactions emerge in children after a disaster included acute separation anxiety from their parents, crying, whining, screaming and did not want to move anywhere or move aimlessly, shaking, fear facial expression and clinging to something or someone else. More severe reaction were feeling stressed or depressed, anxious, guilty feeling, numbness or flat emotions about anything (emotional numbness). Drug addiction, trouble with friends groups and elicits behavior that is not acceptable by the surroundings.

In accordance with the opinion of Muray, trauma may resolved in weeks, but also can have an impact that will be felt for life, even influencing the development process. The results of statistical calculations above showed that environmental changes had significant relationship with tendency to emotional problems $(p>0.05$ and $R R=7.04)$. It can be interpreted that the changes in the environment was a risk factor to tendency of emotional problems. According to McDermott opinion, in natural disasters the children will lose all their possessions, including the environment (shelter, playground, school, friends and other places). Symptoms of emotional distress were significantly associated with environmental damage (Murray, 2006; McDermott, 1999).

A similar study by Bodvarsdottir declared that natural disaster as the biggest cause of stress, which lead to adaptive or pathological reaction in the community. This was because the environment had changed, so that people have to adapt quickly to new circumstances, such as loss of friends, family and all their possessions. The results of these studies is in line with the theory, supported by several previous studies that have been done by McDermott et al 
that reported environmental changes affect the tendency of children's emotional problems (Mc Dermott, 1999).

Statistically, there was no significant association between mother education. After the dependent variable (the tendency of emotional problems), the independent variable (change of environment) as well as external variables (maternal education) were analyzed together, it turned out that external variables still did not have significant relationship with a tendency to emotional problems. Statistical data showed education did not have significant relationship with a tendency to emotional problems of children $p>0.05$.

Higher mother education showed more children with suspected was different from existing theories that mothers with higher education will be able to provide more optimal child development education. The level of education is very influential on improving the quality of human resources. With a high level of education then someone will be able to follow the development of science easily and absorb technological progress, therefore they'll have broader knowledge. The development of a nation is largely determined by the education of their citizens. Women have an important role especially in individual's character building.

As the mother are the first educator for their children. This is consistent with the opinion of Heller (1986), found that higher incomes and those with more education were more can be prepared, because they have greater access to sources of health information. According Werdiningsih (2012), there were association between mother's role in fulfilling the basic needs of children to the development of fine motor, gross motor and social personal of preschool children aged 3-6 years. Parents play an important role in helping children to understand and cope with disasters. A similar study by Proctor showed that the relationship between the earthquake and the child's symptoms can be alleviated with the quality of their affective parental interaction of the mother and father to their child before the disaster and were mediated by parental stress post-disaster (Bryanz, 2002; Heller, 1986).

Statistically, there was no significant association between employment status.
After the dependent variable (the tendency of emotional problems), the independent variable (change of environment) as well as external variables (mother occupation), were analyzed together turned out that external variables had no significant relationship with a tendency to emotional problems. Statistics showed mother employment status did not have significant relationship. There was unknown obvious reasons why working mother have a higher tendency to emotional problems suspected. Though a mother who worked very little time for children so that mothers are less able to monitor the development of children. This probably because when the earthquake occurred, many parents are traumatized too, so for provide safety is also lack. Parents play an important role in helping children to understand and cope with disasters (Bryant, 2002)

Statistically, there was no significant association between employment status. After the dependent variable (the tendency of emotional problems), the independent variable (change of environment) as well as external variables (economic status), analyzed together turned out that external variables had no significant relationship with a tendency to emotional problems. Statistical data showed that economic status of the mother did not have significant relationship with the child's tendency to emotional problems. Similar to opinion of Heller found that higher incomes and those with more education were more can be prepared, because they have greater access to sources of health information (Heller, 1986).

Emotional distress caused by the disaster should be prevented and addressed so that children can do activity as appropriate. As a health worker, one of the things that can be done is through education on disaster preparedness. According to Sasikome (2015), stated that there was differences of disaster preparedness among the group given counseling with a group without given counseling.

Children who become victims urgently need social support, because it is an important factor and it is worthwhile to eliminate postdisaster trauma. Children need those closest especially parents to help relieve the disorder. The support is not only expected from parents but also teachers, siblings, peers and the 
community that will make the children have a good self-confidence, feel welcome, feel recognized and can return to normal life.

\section{Conclusion}

The study concluded that there was significant relationship between changes in the environment caused by the earthquake with a tendency to emotional problems of children aged 1-5 years. Disastrous experience has directly put children in a situation of powerlessness and fear that the tendency to experience emotional problems. Changes in the environment is a risk factor tendency to emotional problems. Impact of the trauma can be resolved in weeks, but also can have an impact that will be felt for life, even influencing individual development. It will affect the way children react to unpleasant experiences, painful and distressing that occur as a result of those traumatic events such as earthquake.

There was significant relationship between parents employment with a tendency to emotional problems in children, children with parents unemployed are more experiencing emotional distress than children with employed parents. There was significant relationship between the economic status of parents with emotional tendencies in children, children with parent that have low economic status experience more emotional distress than children with parents who have a high economic status.

Suggestions for policy makers, research is expected to contribute in making the program of prevention / early detection of handling the problems of post-disaster emotional developmental disorders. In an effort to reduce the risk of a child's tendency to emotional problems caused by the earthquake should provide early detection / prevention to the family level and basic services, and therefore required the participation of parents, especially mothers how early detect the emotional problems of children. For researchers and people who care about children, this research can be used to initiate other studies on the impact of the earthquake on children. The next study is expected to pay more attention to the accuracy of the questionnaire as necessary screening and assessment using valid and reliable instruments that can facilitate interventions aimed at children and families.

\section{References}

Adeola, F.O. 2009. Mental Health \& Psychososial Distress Sequelae of Katrina: An Empirical Study of Survivor, Human Ecology Review 16(2):195-210.

Amawidyati \& Sukma Adi Galuh. 2007. Religiusitas dan Psychological Well-Being Pada Korban Bencana Gempa. Jurnal Psikologi 34(2) : 164176.

Arikunto, Suharsimi. 2010. Prosedur Penelitian. Jakarta: PT. Rineka Cipta.

Bryant. 2002. Non-governmental Organizations And Governmentality: 'Consuming' Biodiversity And Indigenous People in the Philippines. Econpapers. Jurnal Political Studies, 50(2):268-292.

BPS Padang Pariaman. 2010. Geografis. Padang Pariaman: BPS Padang Pariaman.

Heller K, Swindle, Jr., R. W., \& Dusenbury, L. 1986. Component Social Support Process: Comment And Integration. Journal of Consulting and Clinical Psychology, 54: 44670

Hotmaida, Linda. 2008. Kejadian Post Traumatic Syndrom Disorder (PTSD) 8 Bulan Pasca Bencana Tsunami di Kabupaten Ciamis tahun 2007. Jurnal Ilmu Kesehatan Immanuel, 2(2).

Karanci,A.N. \& Rustemli, A. 1995. Psychological Consequences of The 1992 Erzican (Turkey) Earthquake. Disaster, 19:8-18.

Machmud, Rizanda.2009. Peran Petugas Kesehatan Dalam Penanggulan Bencana Alam, Jurnal Kesehatan Masyarakat, 3(1): 28-34.

Mc Dermott BMP, L.J. 1999. Post-disaster Service Provision Following Proactive Identification of Children With Emotional Distress And Depression. Aust N $Z$ J Psychiatry. Vol.33:855-63.

Muray CJS. 2006. Understanding the Effects of Disater on Children, A DevelopmentEcological Approach to Scientific Inquiry. JSPN, 11(3): 199-202.

Nurhasanah. 2009. Relationship Between Level Of Depression And Quality Of Life Of The Community At Disaster Area,Post EarthQuake In The District of Sleman. Berita Kedokteran Masyarakat, 25(1).

Prabandari, Ni Putu Diah., Sukarja, I Made., Maryati, $\mathrm{Ni}$ Luh Gde. 2015. Pengaruh Cognitive Behavioral therapy (CBT) Terhadap Post Traumatic Stress Disorder (PTSD) Pada Pasien Post Kecelakaan Lalu Lintas Di RSUP Sanglah Denpasar. Coping Jurnal, 3(2).

Ristrini., Rukmini., Oktarina. 2012. Analisis 
Implementasi Kebijakan Kesiapsiagaan Bencana Bidang Kesehatan Di Provinsi Sumatera Barat. Penelitian Sistem Kesehatan, 15(1): 91-102.

Rusmiyati, Chatarina. 2012. Penanganan Dampak Social Dan Psikologi Korban Bencana Merapi. Jurnal Informasi, 17(2).

Sasikome, Jacklin Rifka. 2015. Pengaruh Penyuluhan bencana Banjir Terhadap Kesiapsiagaan Siswa SMP Katolik Soegiyo Pranoto Manado Menghadapi Banjir. ejournal Keperawatan (e-Kep), 3(2): 1-8.

Solichah, Mutingatu. 2013. Asesment Post Traumatic Stress Dissorder (PTSD) Pada Perempuan Korban Perkosaan (Acquaitance Rape). Jurnal humanitas, 9(1).

Tentama, Fatwa. 2014. Dukungan Sosial dan PosTraumatik Stress Disorder pada Remaja
Penyitas Gunung Merapi. Jurnal Psikologi Undip, 13 (2):133-138.

Werdiningsih, Ayu Thabita Agustus., Astarani, Kili. 2012. Peran Ibu Dalam Pemenuhan Kebutuhan Dasar Anak Terhadap Perkembangan Anak Usia Prasekolah, Jurnal STIKES, 5(1).

Wuri, Maria Bernadetta. 2008. Perbedaan Profil Kepribadian Anak-Anak Yang Mengalami Gempa Dan Tsunami Aceh Menggunakan Fairy Tale Test, Jurnal Psikologi Indonesia, 12(2).

Zein, Ceisy Alifiani., et al. 2014. Penilaian Dampak Bencana Alam Terhadap Pertumbuhan Ekonomi Wilayah Jangka Pendek (Studi Kasus: Provinsi Sumatera Barat Pasca Bencana Gempa Bumi Tahun 2009). 